\title{
The Millsey Williamson (41RK3), Bead Burial, and L. N. Morwell Farm Sites on Martin Creek: Historic Caddo Settlements along Trammels Trace, Rusk County, Texas
}

Timothy K. Perttula

Heritage Research Center, Stephen F. Austin State University

Bo Nelson

Heritage Research Center, Stephen F. Austin State University

Follow this and additional works at: https://scholarworks.sfasu.edu/ita

Part of the American Material Culture Commons, Archaeological Anthropology Commons, Environmental Studies Commons, Other American Studies Commons, Other Arts and Humanities Commons, Other History of Art, Architecture, and Archaeology Commons, and the United States History Commons

Tell us how this article helped you.

This Article is brought to you for free and open access by the Center for Regional Heritage Research at SFA ScholarWorks. It has been accepted for inclusion in Index of Texas Archaeology: Open Access Gray Literature from the Lone Star State by an authorized editor of SFA ScholarWorks. For more information, please contact cdsscholarworks@sfasu.edu. 


\section{The Millsey Williamson (41RK3), Bead Burial, and L. N. Morwell Farm Sites on Martin Creek: Historic Caddo Settlements along Trammels Trace, Rusk County, Texas}

Creative Commons License

(c) $(1)(9$

This work is licensed under a Creative Commons Attribution-NonCommercial 4.0 International License 


\title{
The Millsey Williamson (41RK3), Bead Burial, and L. N. Morwell Farm Sites on Martin Creek: Historic Caddo Settlements along Trammels Trace, Rusk County, Texas
}

\author{
Timothy K. Perttula and Bo Nelson
}

\section{INTRODUCTION}

There are collections of ceramic vessels and other artifacts from the Millsey Williamson (41RK3), Bead Burial, and L. N. Morwell sites in the Buddy Jones collection at the Gregg County Historical Museum. The purpose of this article is to put the documentation of these collections on record, as this documentation provides previously unavailable detailed information on the material content of probable $18^{\text {th }}$ century Nadaco Caddo/Kinsloe phase historic sites in East Texas.

Based on the limited available information from the Bead Burial and L. N. Morwell Farm sites, it is probable that all three sites are different names for the same Historic Caddo site situated along the Rusk and Panola County line in East Texas (Figure 1) on Trammel's Trace that was reported on by Jones (1968:62-84). The Bead Burial site is reported to be ca. 5 miles south of Tatum along the Rusk-Panola County line, and the Millsey Williamson site is well known for the quantity of glass trade beads found there. The L. M. Morwell Farm site was excavated by C. W. Bailey in 1940, and a tag accompanying two ceramic vessels recovered from a Burial 4 at the site describe it as "Rusk Co. Martin Creek old trading post on Trammels trace."

Jones (1968) indicates that the Millsey Williamson site is an $18^{\text {th }}$ century Nadaco Caddo settlement and cemetery situated on an alluvial terrace on the east side of Martin Creek, a northward-flowing tributary to the Sabine River. Some portions of the site are now covered by the waters of Martin Creek Lake, constructed in the 1970s. The site was first known in the 1930s, when at least 11 historic Caddo burials were excavated in the cemetery at the western end of the landform (Figure 2; see also Jones 1968:Figure 5), and there was a habitation/village area on the highest part of the landform, east of the cemetery. Jones excavated a disturbed historic burial at the site in 1955, and also occasionally collected glass beads from the surface of the site. The funerary offerings placed with this disturbed burial are not clearly enumerated by Jones, as his description of artifacts from the site includes artifacts he examined in several other collections.

He did note 275 sherds from the surface of the site and 12 whole or restored ceramic vessels from an unknown number of burials (Jones 1968:Table 1). Most of these sherds were grog- (52\%) or bone-tempered (43\%), but $4 \%$ were tempered with shell. There were also clay and limonite pipes, ochre and vermillion, animal teeth, glass beads, metal gun parts, gun flints, iron knives, iron arrow points and awls, and a variety of brass objects: a brass tinkler, coils, hawk bells, and unworked pieces of sheet brass.

\section{VESSELS FROM THE SITES}

The vessels from the Gregg County Historical Museum that we documented in July 2013 include 11 from the Millsey Williamson site, five from the Bead Burial site, and two from the L. N. Morwell site. Seven of the vessels from Millsey Williamson can be clearly linked with vessels described and illustrated by Jones (1968:Plates 10 and 11). 


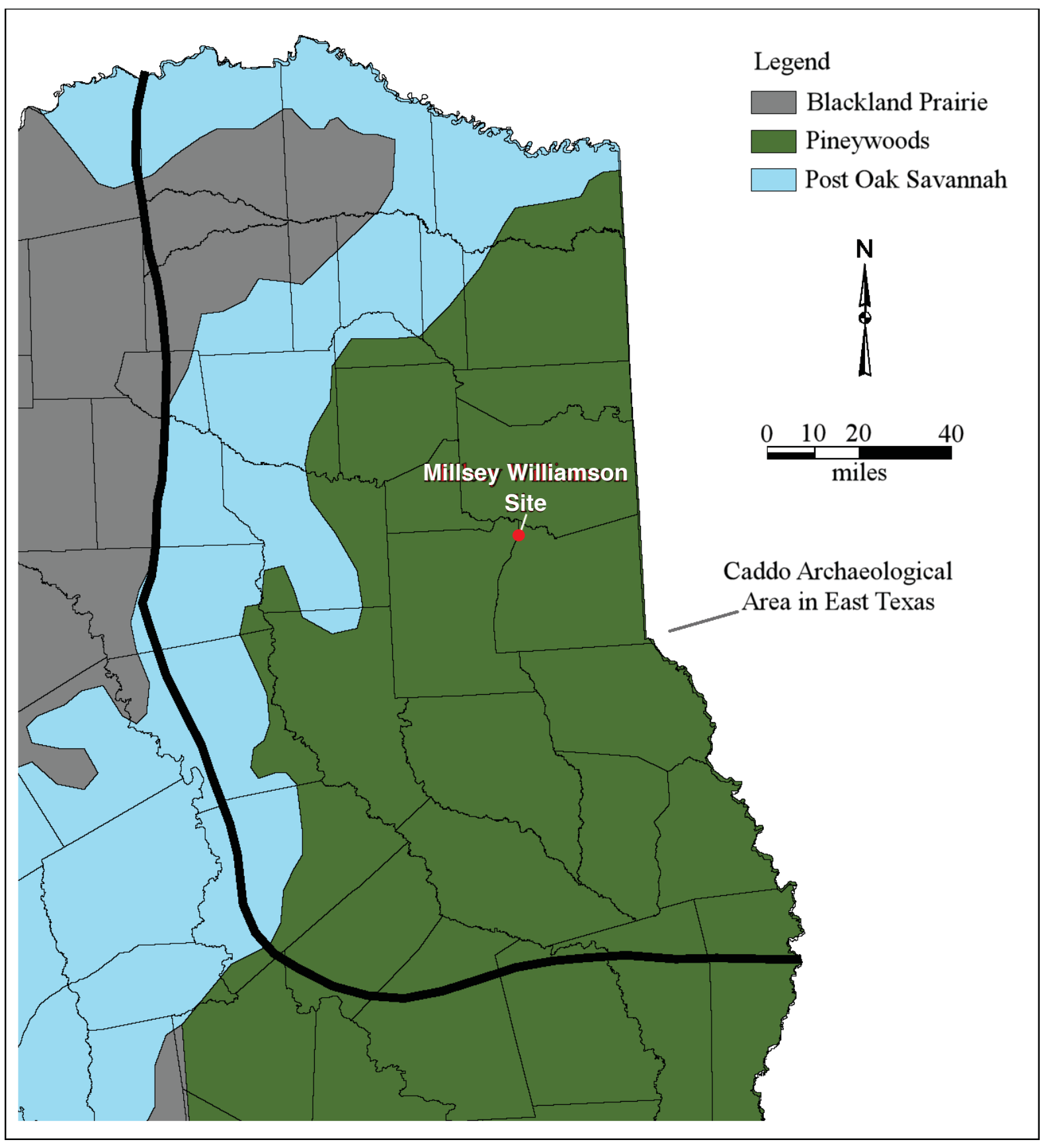

Figure 1. Location of the Millsey Williamson site in East Texas.

SITE NAME OR SITE NUMBER: Millsey Williamson

VESSEL NO.: 2003.08.348

NON-PLASTICS AND PASTE: shell

VESSEL FORM: Collared Jar

RIM AND LIP FORM: Direct and interior beveled rim with a rounded, exterior folded lip 


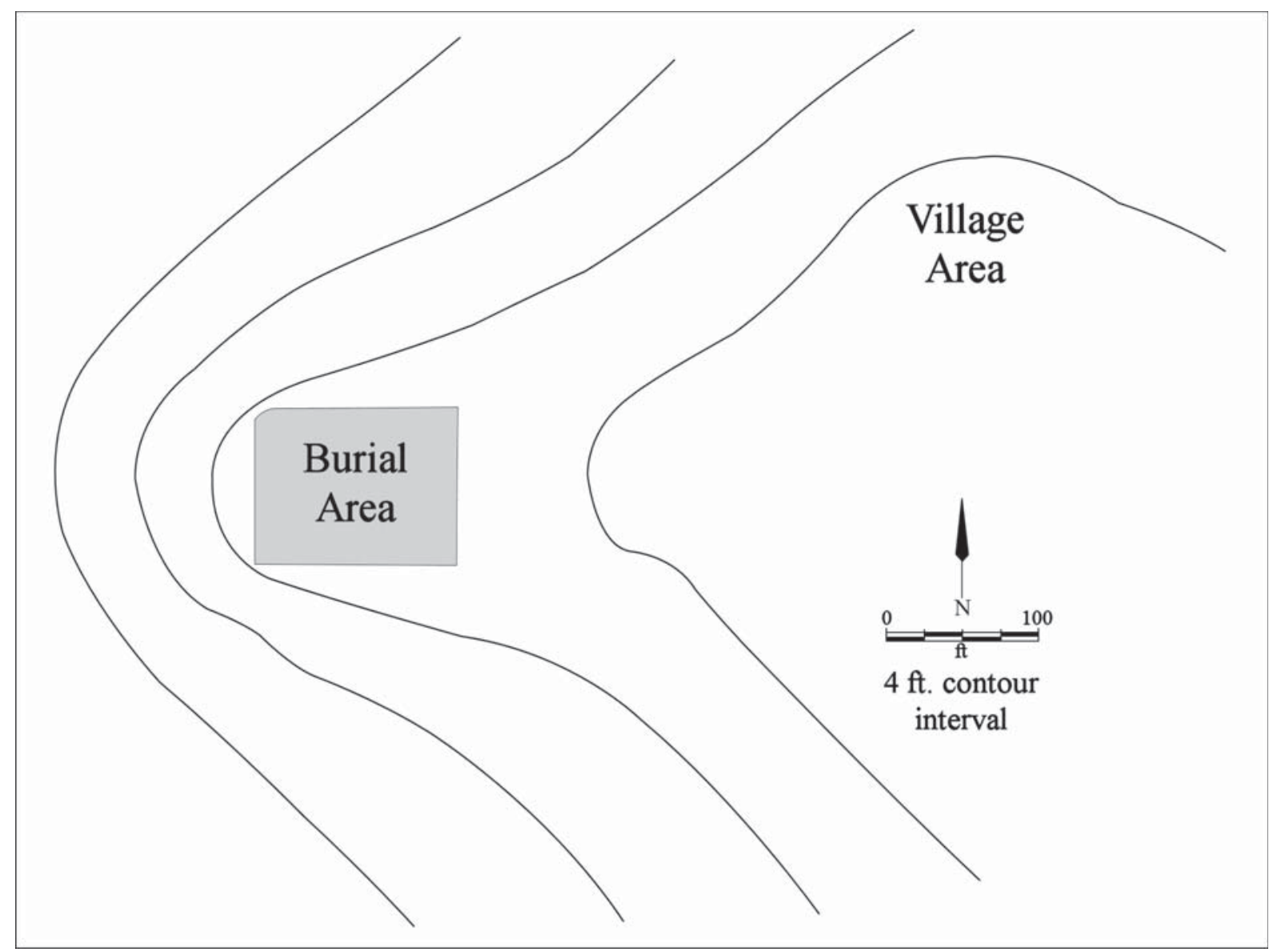

Figure 2. Map of the Millsey Williamson site.

CORE COLOR: F (fired in a reducing vessel and cooled in the open air)

INTERIOR SURFACE COLOR: dark yellowish-brown; fire clouds on the rim and body

EXTERIOR SURFACE COLOR: dark yellowish-brown; fire clouds on the rim, body, and base

WALL THICKNESS (RIM, BODY, AND BASE IN MM): rim, 6.6 mm

INTERIOR SURFACE TREATMENT: smoothed

EXTERIOR SURFACE TREATMENT: none

HEIGHT (IN CM): 15.0

ORIFICE DIAMETER (IN CM): 13.0

DIAMETER AT BOTTOM OF RIM OR NECK (IN CM): 12.6

BASE DIAMETER (IN CM) AND SHAPE OF BASE: 7.6; circular and rounded

ESTIMATED VOLUME (IN LITERS): 0.94 
DECORATION (INCLUDING MOTIF AND ELEMENTS WHEN APPARENT): The rim is decorated with three rows of tool punctations. The vessel body has a negative incised scroll motif repeated five time around the vessel. The negative scrolls are embedded in a zone of regularly-spaced vertical incised lines that extends across the vessel body (Figure 3; see also Jones 1968:Plate 10a-a').

PIGMENT USE AND LOCATION ON VESSEL: none

TYPE AND VARIETY [IF KNOWN]: Emory Punctated-Incised

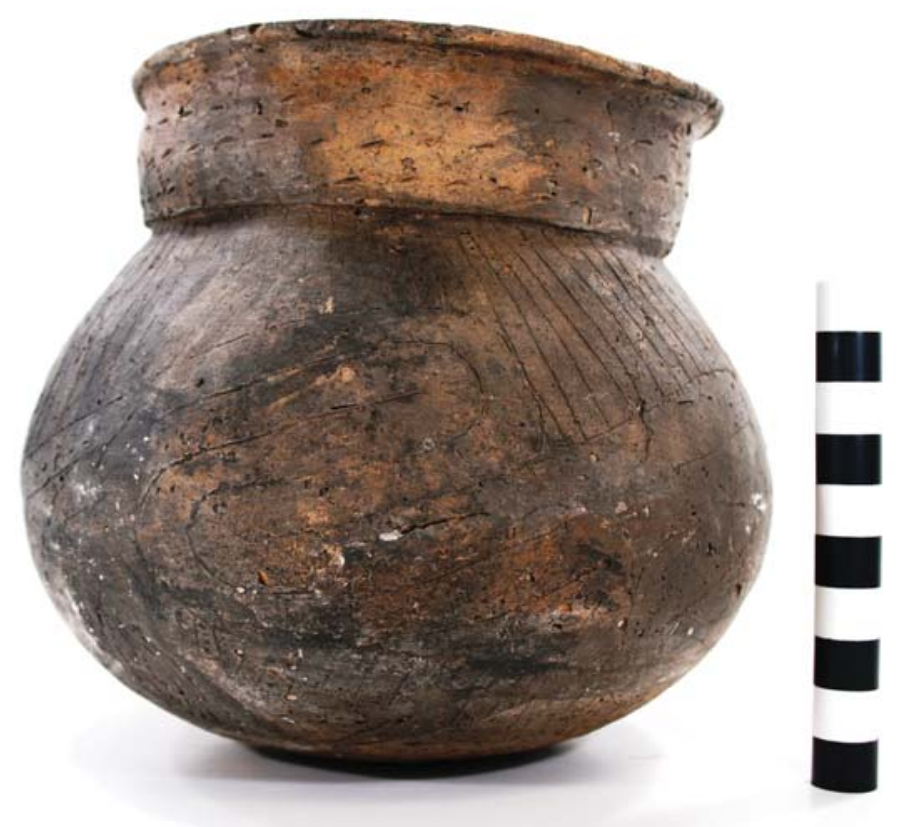

Figure 3. Emory Punctated-Incised jar, Millsey

Williamson site.

SITE NAME OR SITE NUMBER: Millsey Williamson

VESSEL NO.: 2003.08.428

NON-PLASTICS AND PASTE: grog and hematite

VESSEL FORM: Carinated bowl

RIM AND LIP FORM: Direct rim and a rounded, exterior folded lip

CORE COLOR: $\mathrm{G}$ (fired in a reducing environment and cooled in the open air)

INTERIOR SURFACE COLOR: dark grayish-brown; fire clouds on the rim

EXTERIOR SURFACE COLOR: dark yellowish-brown; fire clouds on the rim and body

WALL THICKNESS (RIM, BODY, AND BASE IN MM): rim, $6.2 \mathrm{~mm}$

INTERIOR SURFACE TREATMENT: smoothed on the rim

EXTERIOR SURFACE TREATMENT: burnished 
HEIGHT (IN CM): 12.7

ORIFICE DIAMETER (IN CM): 27.2

DIAMETER AT BOTTOM OF RIM OR NECK (IN CM): 27.0

BASE DIAMETER (IN CM) AND SHAPE OF BASE: 8.9; circular and flat ESTIMATED VOLUME (IN LITERS): 2.1

DECORATION (INCLUDING MOTIF AND ELEMENTS WHEN APPARENT): The rim panel has sets of an opposed engraved oval "eye" motif repeated four times around the vessel; the oval eyes are connected by a rectangular excised element. The sets of "eyes" are separated by nested triangles with negative ovals and hooked arm elements (Figures 4 and 5).

PIGMENT USE AND LOCATION ON VESSEL: white in the engraved lines

TYPE AND VARIETY [IF KNOWN]: cf. Ripley Engraved, var. unspecified

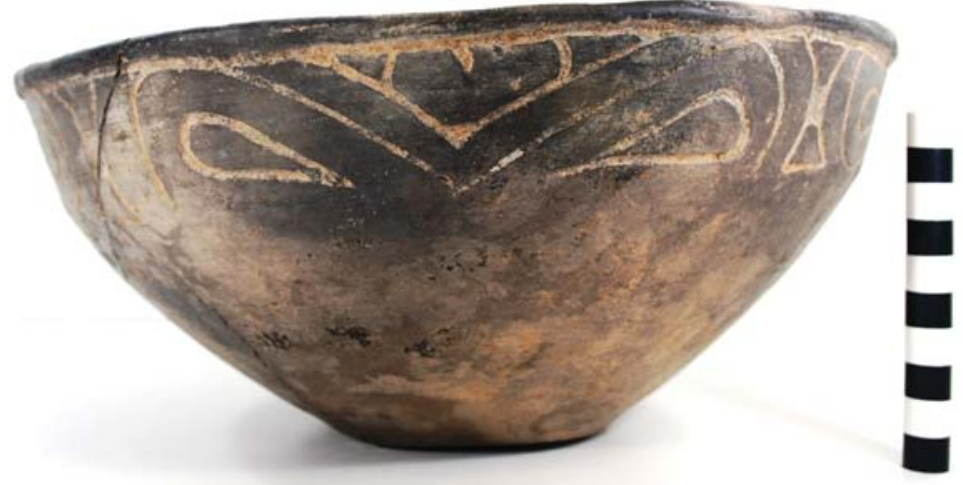

Figure 4. cf. Ripley Engraved, var. unspecified carinated bowl, Millsey Williamson site.

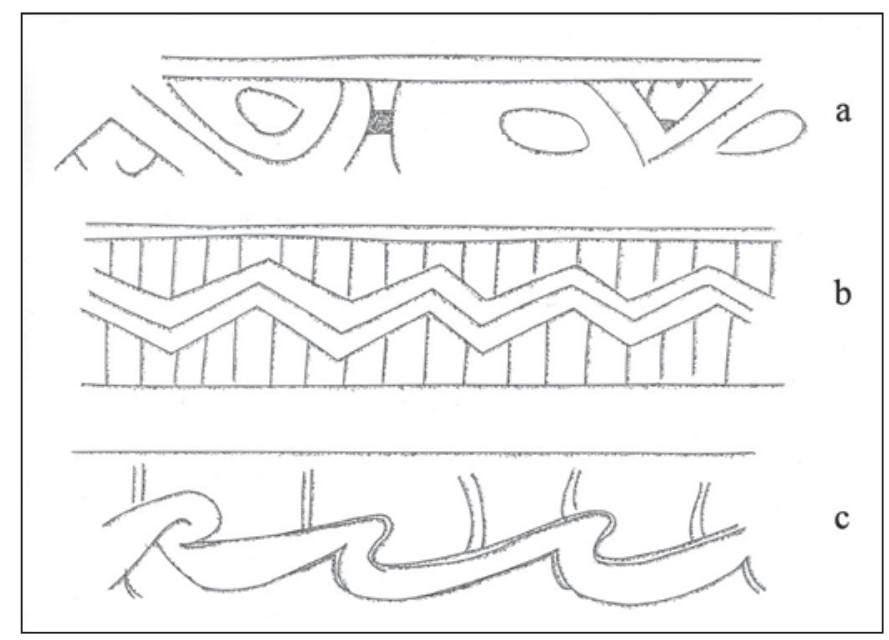

Figure 5. Drawings of engraved motifs on selected vessels: a, Ripley Engraved, var. unspecified carinated bowl from the Millsey Williamson site; $b$, engraved carinated bowl from the Millsey Williamson site; c, engraved carinated bowl from the Millsey Williamson site. 
SITE NAME OR SITE NUMBER: Millsey Williamson

VESSEL NO.: 2003.08.505

NON-PLASTICS AND PASTE: grog and sandy paste

VESSEL FORM: Carinated bowl

RIM AND LIP FORM: Inverted rim and a rounded lip

CORE COLOR: A (fired and cooled in an oxidizing environment)

INTERIOR SURFACE COLOR: reddish-brown

EXTERIOR SURFACE COLOR: reddish-brown

WALL THICKNESS (RIM, BODY, AND BASE IN MM): rim, 6.5 mm

INTERIOR SURFACE TREATMENT: smoothed

EXTERIOR SURFACE TREATMENT:

smoothed

HEIGHT (IN CM): 10.2

ORIFICE DIAMETER (IN CM): 15.8

DIAMETER AT BOTTOM OF RIM OR NECK

(IN CM): 16.3

BASE DIAMETER (IN CM) AND SHAPE OF

BASE: 4.3; circular and flat

ESTIMATED VOLUME (IN LITERS): 1.0

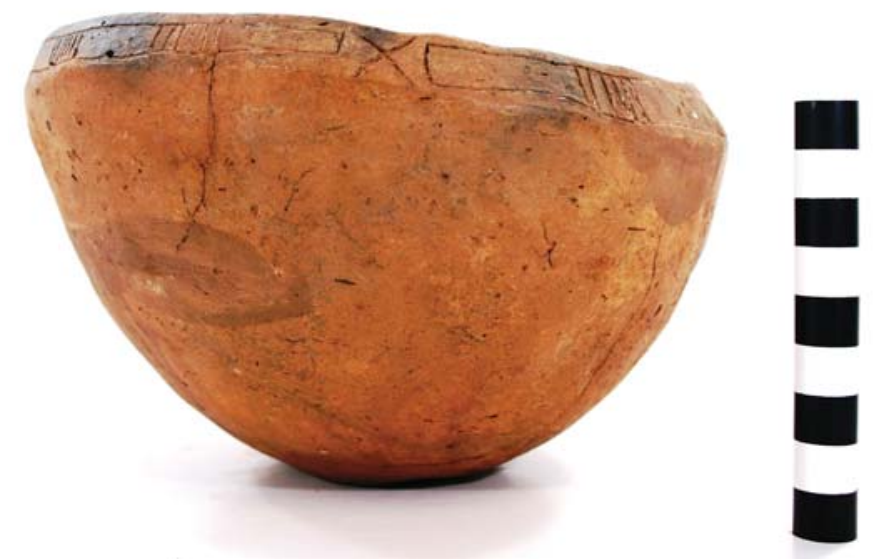

Figure 6. Simms Incised carinated bowl, Millsey Williamson site.

DECORATION (INCLUDING MOTIF AND ELEMENTS WHEN APPARENT): The narrow rim has an incised motif repeated three times around the vessel. The motif includes rectilinear panels with three sets of vertical incised lines. Each motif is divided by an X-shaped incised element (Figure 6; see also Jones 1968:Plate 10d-d').

PIGMENT USE AND LOCATION ON VESSEL: none

TYPE AND VARIETY [IF KNOWN]: Simms Incised (i.e., Simms Engraved vessel form and motif, except the latter is rendered in incised lines) 
SITE NAME OR SITE NUMBER: Millsey Williamson

VESSEL NO.: 2003.08.583

NON-PLASTICS AND PASTE: bone

VESSEL FORM: Collared Carinated bowl

RIM AND LIP FORM: Direct rim and a rounded, exterior folded lip

CORE COLOR: $\mathrm{F}$ (fired in a reducing environment and cooled in the open air)

INTERIOR SURFACE COLOR: reddish-brown; fire clouds on the rim, body, and base

EXTERIOR SURFACE COLOR: light reddishbrown; fire clouds on the rim, body, and base

WALL THICKNESS (RIM, BODY, AND BASE IN MM): rim, 5.6; body, $6.0 \mathrm{~mm}$; base, $8.7 \mathrm{~mm}$

INTERIOR SURFACE TREATMENT: smoothed

EXTERIOR SURFACE TREATMENT: burnished

HEIGHT (IN CM): 8.2

ORIFICE DIAMETER (IN CM): 13.0

DIAMETER AT BOTTOM OF RIM OR NECK (IN CM): 12.8

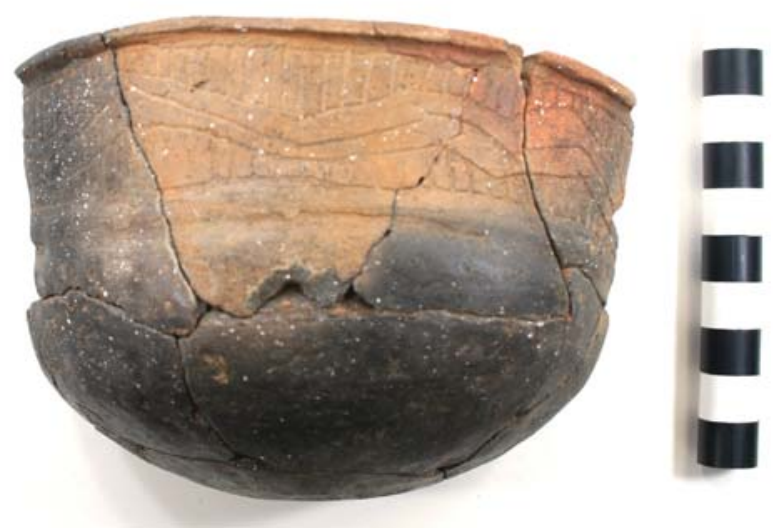

Figure 7. Engraved carinated bowl, Millsey Williamson site.

BASE DIAMETER (IN CM) AND SHAPE OF BASE: 5.3; circular and rounded

ESTIMATED VOLUME (IN LITERS): 0.64

DECORATION (INCLUDING MOTIF AND ELEMENTS WHEN APPARENT): The rim panel has an engraved continuous stepped rectilinear scroll around the vessel. The scroll is embedded in a zone of vertical engraved lines (Figures 5b and 7; see also Jones 1968:Plate 10f).

PIGMENT USE AND LOCATION ON VESSEL: none

TYPE AND VARIETY [IF KNOWN]: Unidentified fine ware 
SITE NAME OR SITE NUMBER: Millsey Williamson

VESSEL NO.: 2003.08.613

NON-PLASTICS AND PASTE: grog

VESSEL FORM: Jar

RIM AND LIP FORM: Direct rim and rounded lip

CORE COLOR: $\mathrm{F}$ (fired in a reducing environment and cooled in the open air)

INTERIOR SURFACE COLOR: dark yellowish-brown

EXTERIOR SURFACE COLOR: dark yellowishbrown; fire clouds on the rim, body, and base

WALL THICKNESS (RIM, BODY, AND BASE IN MM): rim, $5.9 \mathrm{~mm}$

INTERIOR SURFACE TREATMENT: smoothed

EXTERIOR SURFACE TREATMENT: smoothed

HEIGHT (IN CM): 10.8

ORIFICE DIAMETER (IN CM): 12.3

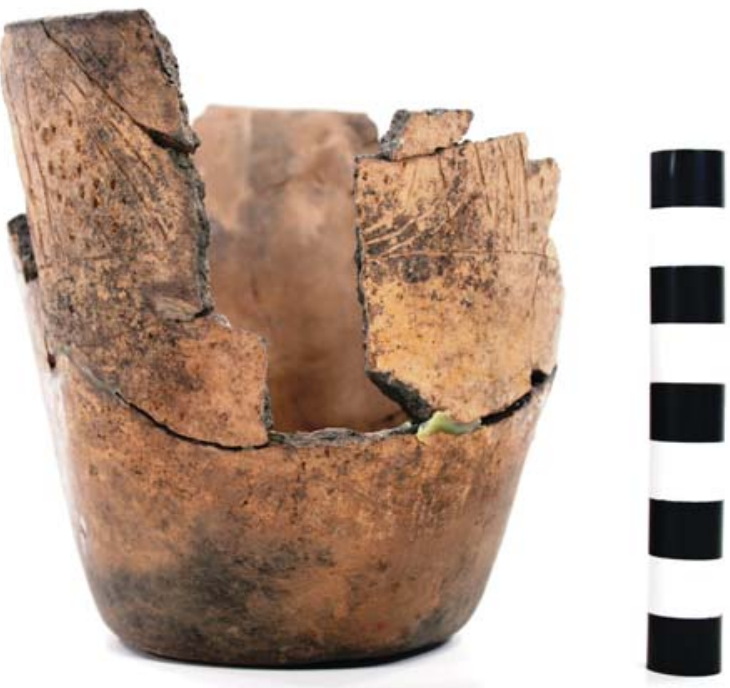

Figure 8. Maydelle Incised jar, Millsey Williamson site.

DIAMETER AT BOTTOM OF RIM OR NECK (IN CM): N/A

BASE DIAMETER (IN CM) AND SHAPE OF BASE: 6.7; circular and flat

ESTIMATED VOLUME (IN LITERS): 0.80

DECORATION (INCLUDING MOTIF AND ELEMENTS WHEN APPARENT): The rim has triangular and circular incised zones filled with small circular tool punctates. The incised circles and triangles are separated by vertical, diagonal, and curvilinear sets of incised lines (Figure 8).

PIGMENT USE AND LOCATION ON VESSEL: none

TYPE AND VARIETY [IF KNOWN]: Maydelle Incised 
SITE NAME OR SITE NUMBER: Millsey Williamson

VESSEL NO.: 2003.08.680

NON-PLASTICS AND PASTE: grog and bone

VESSEL FORM: Carinated bone

RIM AND LIP FORM: Everted rim, interior beveled, and rounded lip

CORE COLOR: F (fired in a reducing environment and cooled in the open air)

INTERIOR SURFACE COLOR: dark yellowish-brown; fire clouds on the rim, body, and base

EXTERIOR SURFACE COLOR: dark yellowish-brown; fire clouds on the rim, body, and base

WALL THICKNESS (RIM, BODY, AND BASE IN MM): rim, 7.6 mm; body, $6.4 \mathrm{~mm}$

INTERIOR SURFACE TREATMENT: smoothed

EXTERIOR SURFACE TREATMENT: smoothed

HEIGHT (IN CM): 11.5

ORIFICE DIAMETER (IN CM): 18.6

DIAMETER AT BOTTOM OF RIM OR NECK

(IN CM): 18.2

BASE DIAMETER (IN CM) AND SHAPE OF

BASE: 8.2; circular and rounded

ESTIMATED VOLUME (IN LITERS): 1.3

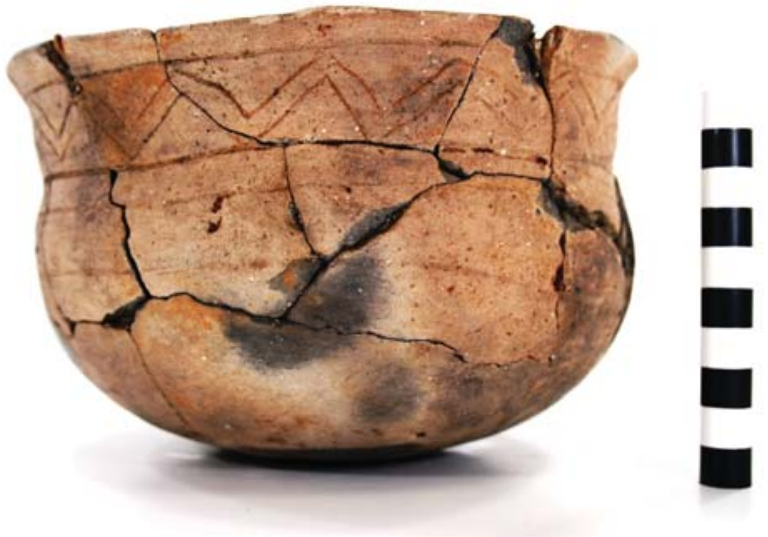

Figure 9. Engraved carinated bowl, Millsey Williamson site.

DECORATION (INCLUDING MOTIF AND ELEMENTS WHEN APPARENT): The rim is decorated with two closely-spaced engraved continuous stepped scrolls. There are two horizontal engraved lines below the stepped scrolls (Figure 9; see also Jones 1968:Plate 10e).

PIGMENT USE AND LOCATION ON VESSEL: none

TYPE AND VARIETY [IF KNOWN]: Unidentified fine ware 
SITE NAME OR SITE NUMBER: Millsey Williamson

VESSEL NO.: 2003.08.775

NON-PLASTICS AND PASTE: bone

VESSEL FORM: Jar

RIM AND LIP FORM: Everted rim and rounded, exterior folded lip

CORE COLOR: F (fired in a reducing environment and cooled in the open air)

INTERIOR SURFACE COLOR: dark reddish-brown; fire clouds on the rim

EXTERIOR SURFACE COLOR: dark reddish-brown; fire clouds on the rim and body

WALL THICKNESS (RIM, BODY, AND BASE IN

MM): rim, $6.5 \mathrm{~mm}$

INTERIOR SURFACE TREATMENT: smoothed

EXTERIOR SURFACE TREATMENT: none

HEIGHT (IN CM): 10.8

ORIFICE DIAMETER (IN CM): 10.4

DIAMETER AT BOTTOM OF RIM OR NECK (IN

CM): 9.0

BASE DIAMETER (IN CM) AND SHAPE OF BASE:

5.1; circular and rounded

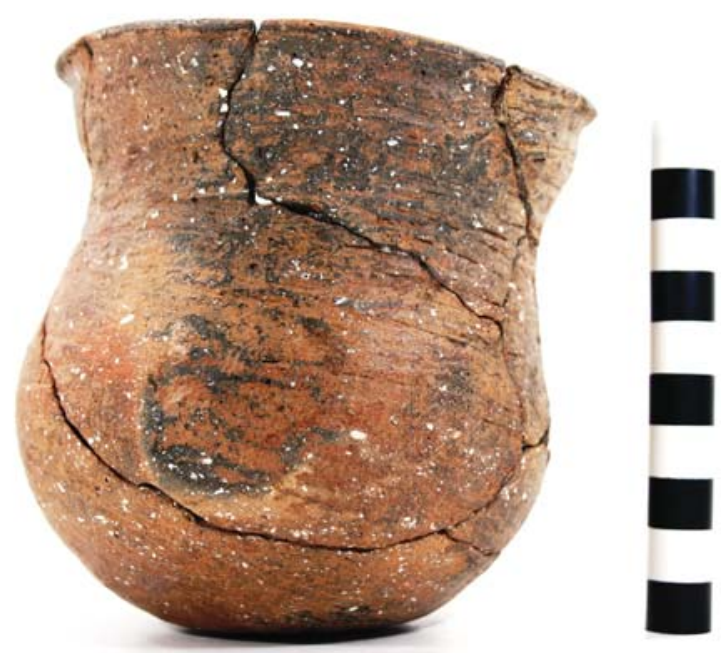

Figure 10. Bullard Brushed jar, Millsey

ESTIMATED VOLUME (IN LITERS): 0.67

Williamson site.

DECORATION (INCLUDING MOTIF AND ELEMENTS WHEN APPARENT): The rim and body are decorated with horizontal brushing marks from just under the lip to the vessel base (Figure 10; see also Jones 1968:Plate 11c).

PIGMENT USE AND LOCATION ON VESSEL: none

TYPE AND VARIETY [IF KNOWN]: Bullard Brushed 
SITE NAME OR SITE NUMBER: Millsey Williamson

VESSEL NO.: 2003.08.884

NON-PLASTICS AND PASTE: bone

VESSEL FORM: Jar with a collared rim (Figure 11)

RIM AND LIP FORM: Direct rim, interior beveled, and rounded lip

CORE COLOR: F (fired in a reducing environment and cooled in the open air)

INTERIOR SURFACE COLOR: dark yellowish-brown; fire clouds on the rim and body

EXTERIOR SURFACE COLOR: dark yellowish-brown; fire clouds on the rim, body, and base

WALL THICKNESS (RIM, BODY, AND BASE IN MM): rim, $5.1 \mathrm{~mm}$; body, $5.6 \mathrm{~mm}$; base, $10.2 \mathrm{~mm}$

INTERIOR SURFACE TREATMENT: smoothed

EXTERIOR SURFACE TREATMENT: none

HEIGHT (IN CM): 21.8

ORIFICE DIAMETER (IN CM): 17.1

DIAMETER AT BOTTOM OF RIM OR NECK (IN CM): 16.2

BASE DIAMETER (IN CM) AND SHAPE OF BASE: 5.1 , circular and flat

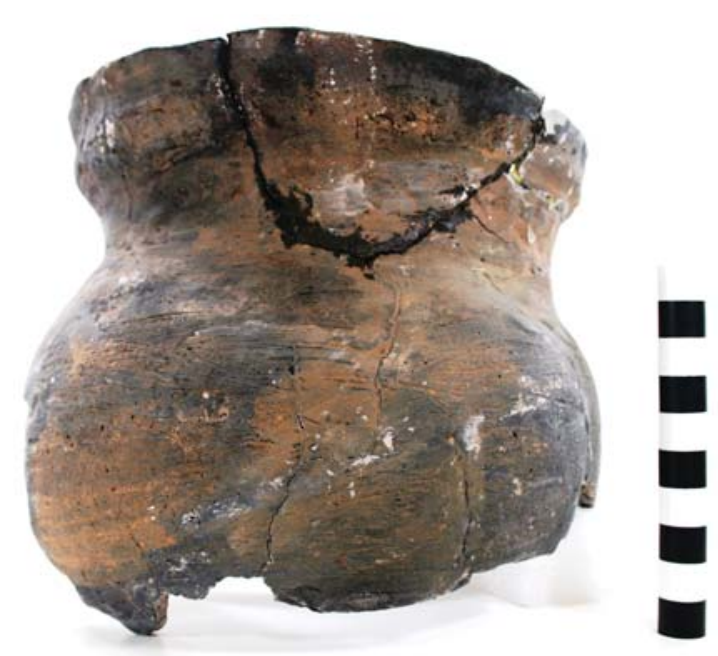

ESTIMATED VOLUME (IN LITERS): 3.4

Figure 11. Brushed collared jar, Millsey Williamson site.

DECORATION (INCLUDING MOTIF AND ELEMENTS WHEN APPARENT): The vessel rim is plain but the vessel body has both horizontal and overlapping brushing marks (Figure 11, see also Jones 1968:Plate $11 \mathrm{e})$.

PIGMENT USE AND LOCATION ON VESSEL: none

TYPE AND VARIETY [IF KNOWN]: Unidentified utility ware 
SITE NAME OR SITE NUMBER: Millsey Williamson

VESSEL NO.: 2003.08.978

NON-PLASTICS AND PASTE: grog

VESSEL FORM: Carinated bowl with a sprocket lip (Figure 12b)

RIM AND LIP FORM: Direct rim and a rounded, exterior folded and flattened lip

CORE COLOR: B (fired and cooled in a reducing environment)

INTERIOR SURFACE COLOR: dark grayishbrown

EXTERIOR SURFACE COLOR: dark grayishbrown

WALL THICKNESS (RIM, BODY, AND BASE

IN MM): rim, $7.0 \mathrm{~mm}$

INTERIOR SURFACE TREATMENT: smoothed

EXTERIOR SURFACE TREATMENT: smoothed

HEIGHT (IN CM): 5.8

ORIFICE DIAMETER (IN CM): 16.6

DIAMETER AT BOTTOM OF RIM OR NECK

(IN CM): 16.0

BASE DIAMETER (IN CM) AND SHAPE OF

BASE: 8.9; circular and rounded

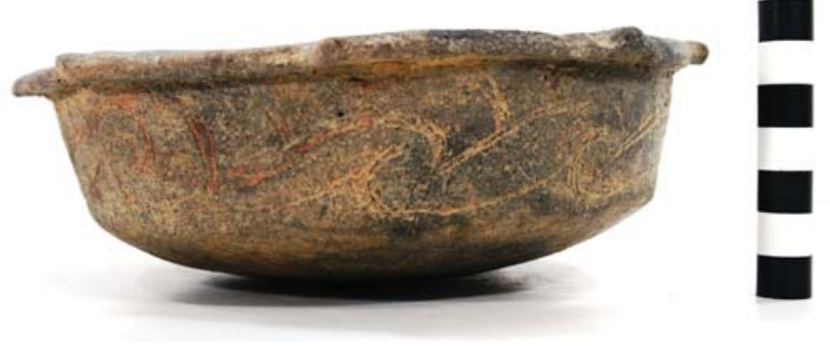

a

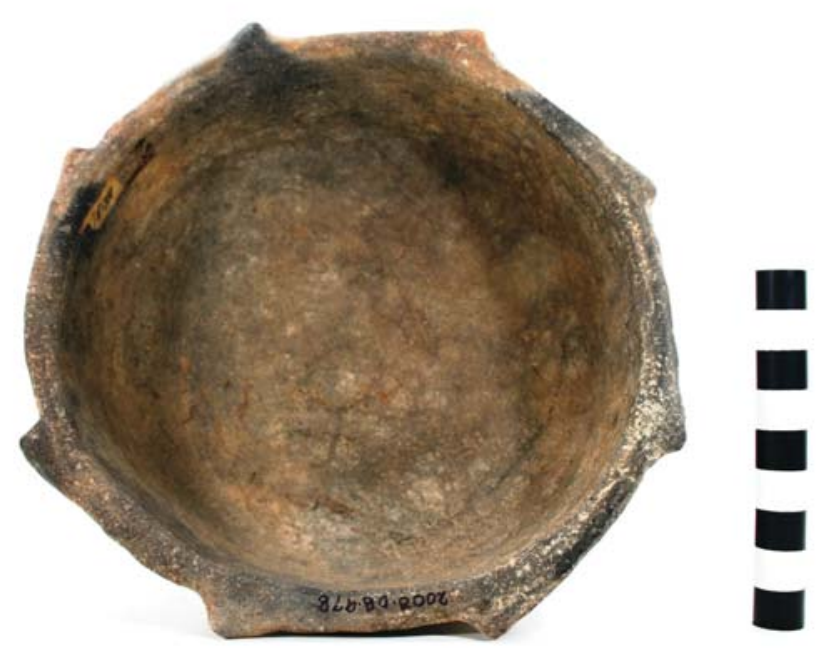

b

Figure 12. Engraved carinated bowl, Millsey Williamson site: a, side view; $b$, view of sprocket lip.

\section{ESTIMATED VOLUME (IN LITERS): 0.58}

DECORATION (INCLUDING MOTIF AND ELEMENTS WHEN APPARENT): The rim panel has a continuous negative scroll repeated eight times around the vessel. One end of the scroll motif ends in a hooked arm element with the upper scroll fill zone. The upper scroll fill zone has sets of vertical and near-vertical engraved lines (Figures 5c and 12a).

PIGMENT USE AND LOCATION ON VESSEL: red pigment in engraved lines

TYPE AND VARIETY [IF KNOWN]: Unidentified fine ware 
SITE NAME OR SITE NUMBER: Millsey Williamson

VESSEL NO.: 2003.08.1961

NON-PLASTICS AND PASTE: bone and hematite

VESSEL FORM: Olla

RIM AND LIP FORM: N/A

CORE COLOR: $\mathrm{H}$ (fired in a reducing environment and cooled in the open air)

INTERIOR SURFACE COLOR: yellowish-brown

EXTERIOR SURFACE COLOR: grayish-brown

WALL THICKNESS (RIM, BODY, AND BASE IN MM): body, $7.1 \mathrm{~mm}$

INTERIOR SURFACE TREATMENT: smoothed

EXTERIOR SURFACE TREATMENT: smoothed

HEIGHT (IN CM): N/A

ORIFICE DIAMETER (IN CM): N/A

DIAMETER AT BOTTOM OF RIM OR NECK (IN CM): N/A

BASE DIAMETER (IN CM) AND SHAPE OF BASE: N/A

ESTIMATED VOLUME (IN LITERS): N/A

DECORATION (INCLUDING MOTIF AND ELEMENTS WHEN APPARENT): Plain (see also Jones 1968:Plate 11c).

PIGMENT USE AND LOCATION ON VESSEL: none

TYPE AND VARIETY [IF KNOWN]: Unidentified plain ware 
SITE NAME OR SITE NUMBER: Millsey Williamson

VESSEL NO.: 2003.08.1077

NON-PLASTICS AND PASTE: grog

VESSEL FORM: Carinated bowl

RIM AND LIP FORM: Direct rim and rounded lip

CORE COLOR: F (fired in a reducing environment and cooled in the open air)

INTERIOR SURFACE COLOR: dark reddish-brown; fire clouds on the body and base

EXTERIOR SURFACE COLOR: dark yellowish-brown; fire clouds on the rim and base

WALL THICKNESS (RIM, BODY, AND BASE IN MM): rim, $4.6 \mathrm{~mm}$; body, $7.1 \mathrm{~mm}$; base, $6.9 \mathrm{~mm}$

INTERIOR SURFACE TREATMENT: smoothed

EXTERIOR SURFACE TREATMENT: burnished

HEIGHT (IN CM): 8.2

ORIFICE DIAMETER (IN CM): 18.5

DIAMETER AT BOTTOM OF RIM OR NECK (IN CM): 18.3

BASE DIAMETER (IN CM) AND SHAPE OF BASE: 6.3; circular and flat

ESTIMATED VOLUME (IN LITERS): 0.90

DECORATION (INCLUDING MOTIF AND ELEMENTS WHEN APPARENT): The rim panel has a continuous series of diagonal opposed and cross-hatched engraved lines (Figure 13).

PIGMENT USE AND LOCATION ON VESSEL: red in engraved lines

TYPE AND VARIETY [IF KNOWN]: Unidentified fine ware

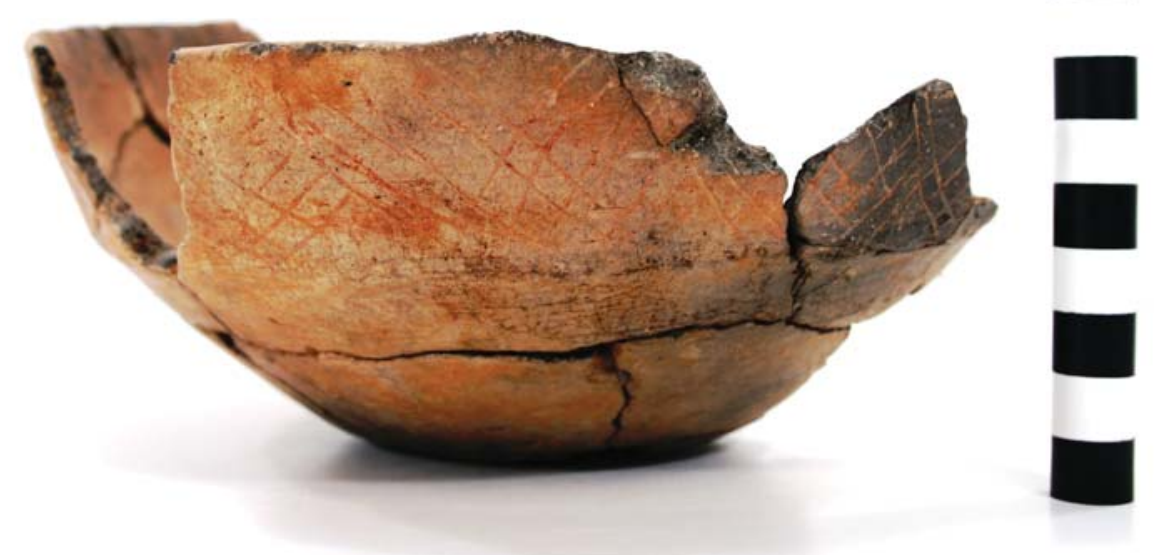

Figure 13. Engraved carinated bowl, Millsey Williamson site. 
SITE NAME OR SITE NUMBER: Bead Burial

VESSEL NO.: 2003.08.1230, Vessel No. 1

NON-PLASTICS AND PASTE: grog

VESSEL FORM: Carinated bowl

RIM AND LIP FORM: Direct rim and rounded lip

CORE COLOR: $\mathrm{F}$ (fired in a reducing environment and cooled in the open air)

INTERIOR SURFACE COLOR: yellowish-brown; fire clouds on the base

EXTERIOR SURFACE COLOR: yellowish-brown; fire clouds on the body and base

WALL THICKNESS (RIM, BODY, AND

BASE IN MM): rim, $6.1 \mathrm{~mm}$; body, $6.5 \mathrm{~mm}$

INTERIOR SURFACE TREATMENT:

smoothed

EXTERIOR SURFACE TREATMENT:

smoothed

HEIGHT (IN CM): N/A

ORIFICE DIAMETER (IN CM): 17.0

DIAMETER AT BOTTOM OF RIM OR

NECK (IN CM): 17.0

BASE DIAMETER (IN CM) AND SHAPE

OF BASE: N/A

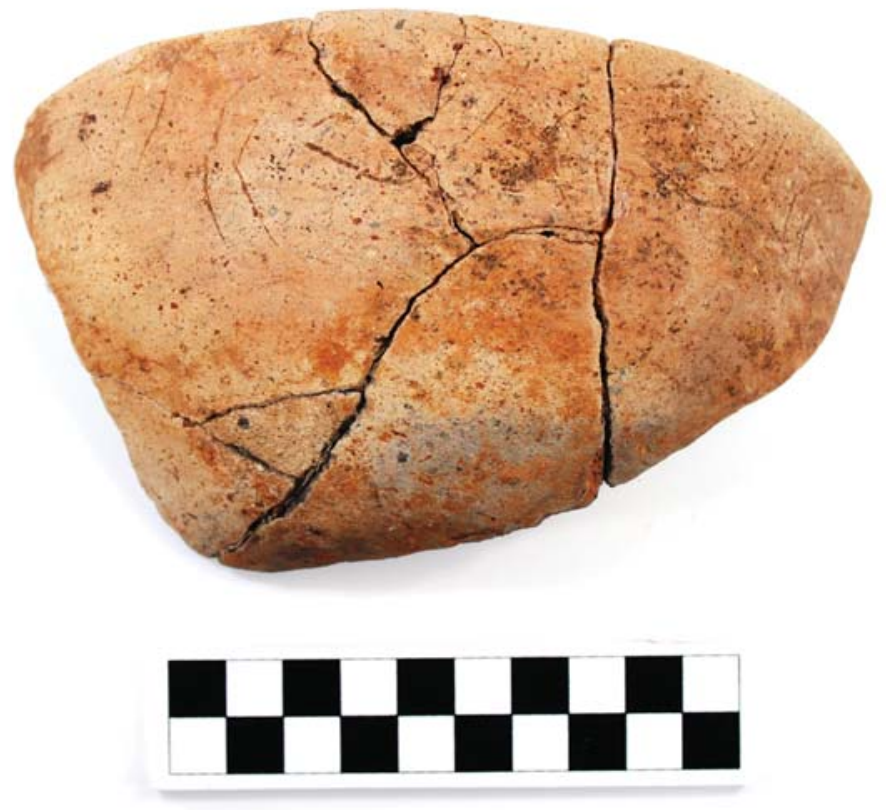

ESTIMATED VOLUME (IN LITERS):

N/A

Figure 14. Engraved carinated bowl rim section, Vessel No. 1, Bead Burial.

DECORATION (INCLUDING MOTIF AND ELEMENTS WHEN APPARENT): The rim panel has an unknown number of series of two upper and lower curvilinear engraved lines that hook around each other around the vessel (Figure 14).

PIGMENT USE AND LOCATION ON VESSEL: none

TYPE AND VARIETY [IF KNOWN]: Unidentified fine ware 
SITE NAME OR SITE NUMBER: Bead Burial

VESSEL NO.: 2003.08.1231, Vessel No. 2

NON-PLASTICS AND PASTE: grog

VESSEL FORM: Compound bowl

RIM AND LIP FORM: Everted rim and rounded lip

CORE COLOR: F (fired in a reducing environment and cooled in the open air)

INTERIOR SURFACE COLOR: yellowish-brown

EXTERIOR SURFACE COLOR: yellowishbrown

WALL THICKNESS (RIM, BODY, AND BASE IN MM): upper rim panel, $4.9 \mathrm{~mm}$; lower rim panel, $4.9 \mathrm{~mm}$

INTERIOR SURFACE TREATMENT: smoothed

EXTERIOR SURFACE TREATMENT:

smoothed

HEIGHT (IN CM): N/A

Figure 15. Plain compound bowl rim section, Vessel No. 2,

ORIFICE DIAMETER (IN CM): 18.3 Bead Burial site.

DIAMETER AT BOTTOM OF RIM OR NECK (IN CM): 17.6

BASE DIAMETER (IN CM) AND SHAPE OF BASE: N/A

ESTIMATED VOLUME (IN LITERS): N/A

DECORATION (INCLUDING MOTIF AND ELEMENTS WHEN APPARENT): Plain (Figure 15)

PIGMENT USE AND LOCATION ON VESSEL: none

TYPE AND VARIETY [IF KNOWN]: Unidentified plain ware 
SITE NAME OR SITE NUMBER: Bead Burial

VESSEL NO.: 2003.08.1232, Vessel No. 3

NON-PLASTICS AND PASTE: bone

VESSEL FORM: Jar

RIM AND LIP FORM: N/A

CORE COLOR: $\mathrm{H}$ (fired in a reducing environment and cooled in the open air)

INTERIOR SURFACE COLOR: dark yellowish-brown; fire clouds on the rim and body

EXTERIOR SURFACE COLOR: black

WALL THICKNESS (RIM, BODY, AND BASE IN MM): body, $7.4 \mathrm{~mm}$; base, $8.8 \mathrm{~mm}$

INTERIOR SURFACE TREATMENT: smoothed

EXTERIOR SURFACE TREATMENT: none

HEIGHT (IN CM): N/A

ORIFICE DIAMETER (IN CM): 14.5+

DIAMETER AT BOTTOM OF RIM OR NECK (IN CM): N/A

BASE DIAMETER (IN CM) AND SHAPE OF BASE: 6.6; circular and flat

ESTIMATED VOLUME (IN LITERS): N/A

DECORATION (INCLUDING MOTIF AND ELEMENTS WHEN APPARENT): The vessel has horizontal brushing marks on the body.

PIGMENT USE AND LOCATION ON VESSEL: none

TYPE AND VARIETY [IF KNOWN]: Unidentified utility ware 
SITE NAME OR SITE NUMBER: Bead Burial

VESSEL NO.: 2003.08.1233, Vessel No. 4

NON-PLASTICS AND PASTE: grog

VESSEL FORM: Jar

RIM AND LIP FORM: Everted rim and rounded lip

CORE COLOR: $\mathrm{G}$ (fired in a reducing environment and cooled in the open air)

INTERIOR SURFACE COLOR: dark reddish-brown; fire clouds on the rim and body; organic residue on the rim and body

EXTERIOR SURFACE COLOR: reddish-brown; fire clouds on the rim and body

WALL THICKNESS (RIM, BODY, AND BASE IN $\mathrm{MM}$ ): rim, $8.3 \mathrm{~mm}$; body, $8.1 \mathrm{~mm}$

INTERIOR SURFACE TREATMENT: smoothed

EXTERIOR SURFACE TREATMENT: none

HEIGHT (IN CM): N/A

ORIFICE DIAMETER (IN CM): 19.0

DIAMETER AT BOTTOM OF RIM OR NECK (IN CM): 18.2

BASE DIAMETER (IN CM) AND SHAPE

OF BASE: N/A

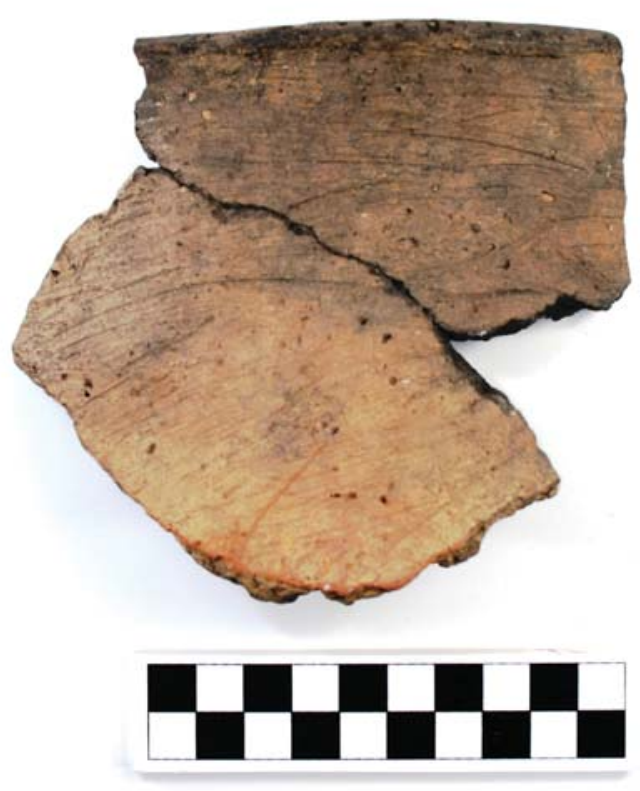

Figure 16. Brushed jar rim and body sherd, Vessel No. 4, Bead Burial site.

ESTIMATED VOLUME (IN LITERS): N/A

DECORATION (INCLUDING MOTIF AND ELEMENTS WHEN APPARENT): The vessel is decorated with horizontal brushing marks on both the rim and body (Figure 16).

PIGMENT USE AND LOCATION ON VESSEL: none

TYPE AND VARIETY [IF KNOWN]: Unidentified utility ware 
SITE NAME OR SITE NUMBER: Bead Burial

VESSEL NO.: 2003.08.1234, Vessel No. 5

NON-PLASTICS AND PASTE: grog

VESSEL FORM: Carinated bowl

RIM AND LIP FORM: N/A

CORE COLOR: F (fired in a reducing environment and cooled in the open air)

INTERIOR SURFACE COLOR: yellowish-brown

EXTERIOR SURFACE COLOR: yellowish-brown; fire clouds on the body and base

WALL THICKNESS (RIM, BODY, AND BASE IN MM): body, $5.1 \mathrm{~mm}$; base, $8.3 \mathrm{~mm}$

INTERIOR SURFACE TREATMENT: smoothed

EXTERIOR SURFACE TREATMENT: smoothed

HEIGHT (IN CM): N/A

ORIFICE DIAMETER (IN CM): N/A

DIAMETER AT BOTTOM OF RIM OR NECK (IN CM): N/A

BASE DIAMETER (IN CM) AND SHAPE OF BASE: N/A

ESTIMATED VOLUME (IN LITERS): N/A

DECORATION (INCLUDING MOTIF AND ELEMENTS WHEN APPARENT): Plain

PIGMENT USE AND LOCATION ON VESSEL: none

TYPE AND VARIETY [IF KNOWN]: Unidentified plain ware 
SITE NAME OR SITE NUMBER: L. N. Morwell Farm

VESSEL NO.: 2003.08.99, Burial 4

NON-PLASTICS AND PASTE: grog

VESSEL FORM: Jar with two suspension holes (both $3.1 \mathrm{~mm}$ in diameter)

RIM AND LIP FORM: Direct rim and rounded lip

CORE COLOR: A (fired and cooled in an oxidizing environment)

INTERIOR SURFACE COLOR: reddish-brown

EXTERIOR SURFACE COLOR: reddish-brown; fire clouds on the body and base

WALL THICKNESS (RIM, BODY, AND BASE

IN MM): rim, $4.7 \mathrm{~mm}$

INTERIOR SURFACE TREATMENT: smoothed

EXTERIOR SURFACE TREATMENT: burnished

HEIGHT (IN CM): 7.6

ORIFICE DIAMETER (IN CM): 6.6

DIAMETER AT BOTTOM OF RIM OR NECK (IN CM): 6.1

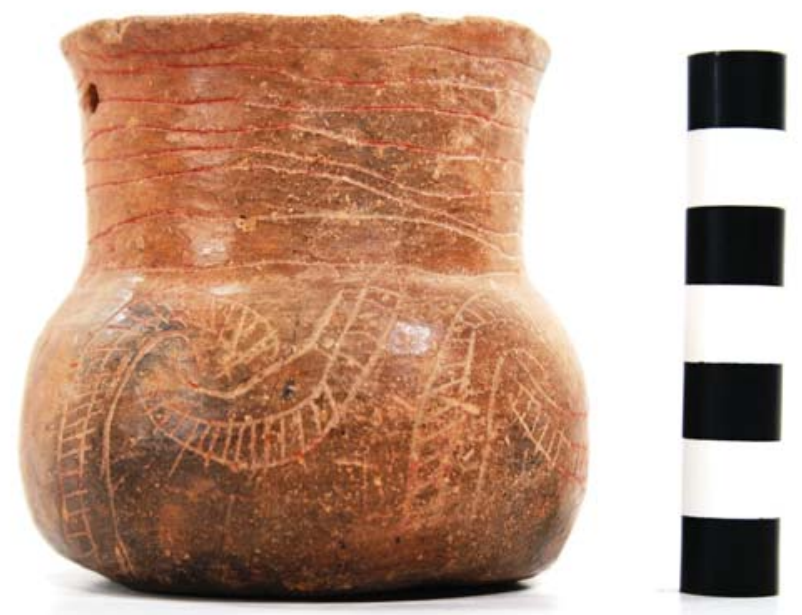

Figure 17. Engraved jar, Burial 4 at the L. N. Morwell Farm site.

BASE DIAMETER (IN CM) AND SHAPE OF BASE: 6.3; circular and flat

ESTIMATED VOLUME (IN LITERS): 0.30

DECORATION (INCLUDING MOTIF AND ELEMENTS WHEN APPARENT): The rim has eight horizontal engraved lines; the suspension holes are between the second and third lines down from the top of the rim. The vessel body has a continuous series of engraved and narrow hatched hooked arm elements that repeat around the vessel (Figure 17).

PIGMENT USE AND LOCATION ON VESSEL: red pigment in the engraved lines

TYPE AND VARIETY [IF KNOWN]: Unidentified fine ware 
SITE NAME OR SITE NUMBER: L. N. Morwell Farm

VESSEL NO.: 2003.08.341, Burial 4

NON-PLASTICS AND PASTE: grog and hematite

VESSEL FORM: Bowl

RIM AND LIP FORM: Direct rim and rounded lip

CORE COLOR: A (fired and cooled in an oxidizing environment)

INTERIOR SURFACE COLOR: reddish-brown

EXTERIOR SURFACE COLOR: reddish-brown; fire clouds on the rim, body, and base

WALL THICKNESS (RIM, BODY, AND BASE IN MM): rim, 4.8 mm

INTERIOR SURFACE TREATMENT: smoothed

EXTERIOR SURFACE TREATMENT: smoothed

HEIGHT (IN CM): 3.8

ORIFICE DIAMETER (IN CM): 10.3

DIAMETER AT BOTTOM OF RIM OR NECK (IN CM): N/A

BASE DIAMETER (IN CM) AND SHAPE OF BASE: 4.4; circular and flat

ESTIMATED VOLUME (IN LITERS): 0.16

DECORATION (INCLUDING MOTIF AND ELEMENTS WHEN APPARENT): The rim has a continuous series of diagonal opposed and cross-hatched engraved lines around the vessel (Figure 18).

PIGMENT USE AND LOCATION ON VESSEL: none

TYPE AND VARIETY [IF KNOWN]: Unidentified fine ware
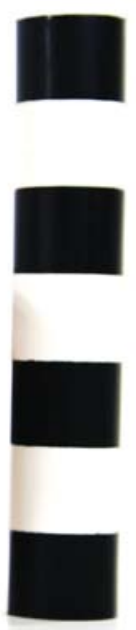

Figure 18. Engraved carinated bowl, Burial 4,L. N. Morwell Farm site. 


\section{SUMMARY OF THE CERAMIC VESSELS}

The vessels from the Millsey Williamson, Bead Burial, and L. N. Morwell sites have a variety of temper and paste combinations. More than $94 \%$ have clay or silty pastes, and one vessel has a sandy paste. Approximately $50 \%$ of the vessels are tempered with grog, $22 \%$ with bone, $11 \%$ with grog and hematite, $5.5 \%$ with grog and bone, $5.5 \%$ with bone and hematite, and $5.5 \%$ with shell. This latter vessel is the only one that is likely not to have been made with local clays.

More than $83 \%$ of the vessels $(n=15)$ were fired in reducing or low oxygen conditions, and the remainder were fired and cooled in a high oxygen or oxidizing environment. Of the vessels fired in a reducing environment, $87 \%$ were cooled in the open air, leaving a thin oxidized zone in the vessel core on either one or both vessel surfaces.

Carinated bowls (44\%) and jars (39\%) are the most common vessel forms in the vessel assemblage. One of the carinated bowls has a sprocket rim (see Walters 2010) and one of the jars has a collared rim. Other forms represented are single examples of bowls, compound bowls, and ollas.

Approximately $17 \%$ of the vessels are plain; this includes an olla, a compound bowl, and a carinated bowl. The decorated vessels include engraved fine wares (53\% of the decorated vessels), an incised vessel of a form and decorative style that suggests it is also a fine ware (Simms Incised), and six utility ware vessels (40\% of the decorated vessels). These include four brushed jars, one incised jar, and a punctated-incised jar. Few of the vessels can be confidently assigned to a currently defined East Texas ceramic type, namely an Emory Punctated-Incised jar, a Maydelle Incised jar, a Bullard Brushed jar, and a Ripley Engraved, var. unspecified carinated bowl. Other utility wares have a plain rim and a brushed body or horizontal brushing on the rim and/or the body. Unidentified fine wares include two carinated bowls with slanted and stepped scroll motifs, two others have diagonal opposed and cross-hatched engraved lines, and two more vessels have hooked arm elements.

\section{EUROPEAN TRADE GOODS}

A few of the European trade goods recovered in the excavations by Jones at the Millsey Williamson site are present in the Gregg County Historical Museum collections; the other goods mentioned by Jones, particularly the glass beads, have not been located to date, primarily because of the lack of provenience information provided in Jones' notes and records.

The European trade goods that have been identified as coming from the Millsey Williamson site include a flat unworked sheet brass fragment only $0.9 \mathrm{~mm}$ thick (Figure 19c; see also Jones 1968:Plate 14m), a brass tinkler $27.0 \mathrm{~mm}$ in length and $5.1 \mathrm{~mm}$ in width (Figure 19d; see also Jones 1968:Plate 14i) that was rolled into shape (see Harper et al. 1967:92), and a brass hawk bell (Figure 19e; see Jones 1968:Plate 14j). The flush-edge hawk bell (see Harper et al. 1967:87) is $16.0 \mathrm{~mm}$ in height and $15.2 \mathrm{~mm}$ in width; the eye of the hawk bell is $3.7 \mathrm{~mm}$ in height.

Also in the collection is a honey-colored chert French blade gunflint (see Figure 19a). There are striking facets on the dorsal side of the gunflint. It is $25.5 \mathrm{~mm}$ in length, $18.0 \mathrm{~mm}$ in width, and $4.5 \mathrm{~mm}$ in thickness (see also Jones 1968:Plate 14a). Finally, there is a brass gun part, a butt plate finial fragment (see Blaine and Harris 1967:Figure 26). The piece has a perforated tongue for fastening to the butt end of a flintlock musket (see Figure 19b), and there are two horizontal engraved lines on the exterior side of the fragment (see also Jones 1968:Plate 14e). 


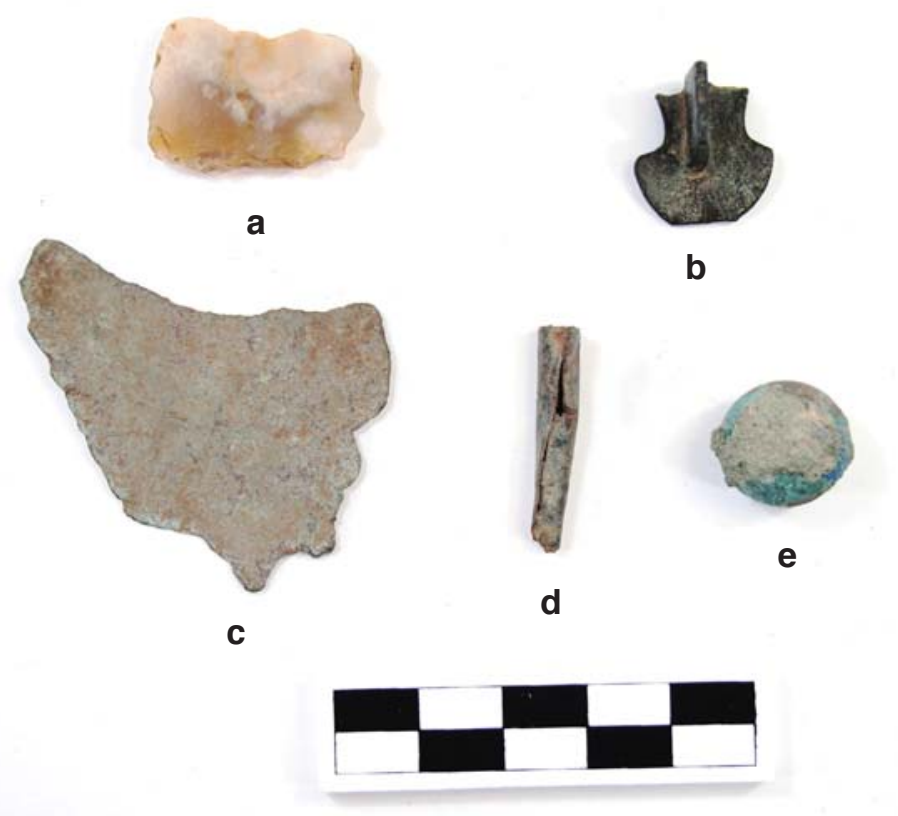

Figure 19. European trade goods from the Millsey Williamson site: a, French gunflint; $b$, butt plate finial fragment; c, sheet brass fragment; d, brass tinkler; e, brass hawk bell.

\section{SUMMARY AND CONCLUSIONS}

The Millsey Williamson site is an 18th century Nadaco Caddo settlement and cemetery on Martin Creek in the East Texas Pineywoods, and there is a collection of ceramic vessels and European trade goods at the Gregg County Historical Museum (GCHM) that we documented in July 2013. Based on locational information in the Buddy Jones collection notes and records, the Bead Burial site and the L. N. Morwell Farm sites, also with collections at the GCHM, may be other names for the Millsey Williamson site.

Most of the collections from these localities are ceramic vessels $(n=18)$ of diverse manufacture, form, and decorative methods. Most are carinated bowls and jars tempered with grog and bone, and fired in a reducing environment, and the former are decorated with engraved lines, while the latter are decorated incised, punctated, or brushed utility wares. On their own stylistic merits, none of these vessels in the GCHM collections are that of a recognizable Historic Caddo type, such as Natchitoches Engraved, Simms Engraved, var. Darco, or Keno Trailed, and in fact, most of these vessels cannot be identified as examples of specific types. The vessels that can be typed include Emory Punctated-Incised, Maydelle Incised, and Bullard Brushed jars and a Ripley Engraved, var. unspecified carinated bowl; one vessel has been dubbed Simms Incised because it is of a form and decorative style that matches Simms Engraved, except the motif is executed with incised lines.

The few European trade goods from the Millsey Williamson site in the GCHM collections are consistent with a post-mid-18th century Caddo occupation. Although the beads from the site cannot be accounted for in the collections, other goods include brass tinklers and hawk bells, a French blade gunflint, and a butt plate finial from a French flintlock musket. 


\section{ACKNOWLEDGMENTS}

We thank Patti Haskins of the Gregg County Historical Museum for all her help in completing the documentation of these materials from the Millsey Williamson and related sites. Lance Trask prepared the vessel design drawings.

\section{REFERENCES CITED}

Blaine, J. C. and R. K. Harris

1967 Guns. In "The Gilbert Site: A Norteno Focus Site in Northeastern Texas," edited by E. B. Jelks. Bulletin of the Texas Archeological Society 37:33-86.

Harper, L., R. Harper, R. K. Harris, I. M. Harris, E. B. Jelks, and J. N. Woodall

1967 Ornaments. In "The Gilbert Site: A Norteno Focus Site in Northeastern Texas," edited by E. B. Jelks. Bulletin of the Texas Archeological Society 37:87-104.

Jones, B. C.

1968 The Kinsloe Focus: A Study of Seven Historic Caddoan Sites in Northeast Texas. Master's thesis, Department of Anthropology, University of Oklahoma, Norman.

Walters, M., with contributions by T. Middlebrook and T. K. Perttula

2010 Redwine or Pie-Crust Mode Forms in East Texas Caddo Ceramics and comparisons with Sprocket-Rims of Southwest Arkansas. Caddo Archeology Journal 20:77-128. 